\title{
SMME Owners' Financial Literacy and Business Growth
}

\author{
Eresia-Eke C.E. \\ Raath C. \\ University of Pretoria, Department of Business Management, South Africa, \\ Email: chuks.eresia-eke@up.ac.za
}

Doi:10.5901/mjss.2013.v4n13p397

\begin{abstract}
The study sought to investigate a possible relationship between SMME owners' financial literacy and business growth. Relationships between the SMME owners' financial literacy and several aspects of possible business growth along the broad dimensions of financial, strategic and structural growth were also explored. To achieve this though, the study had to first establish whether SMME owners were financially literate or otherwise and whether their businesses showed some forms of growth. Primary data was collected in a cross-sectional manner, from a sample of small businesses drawn from a local chamber of commerce in the Gauteng Province of South Africa. The study empirically demonstrated that most small businesses showed signs of growth. The growth signs were however, predominantly along the financial and strategic growth dimensions rather than the structural dimension. Indeed, along the more tangible structural dimension, majority of SMMEs seemed to have stagnated. Curiously, the study was unable to demonstrate that a statistically significant relationship existed between owners' financial literacy and the broad construct of business growth. Even when this broad construct was decomposed into different growth indicators drawn from the financial, strategic and structural growth dimensions, similar statistically insignificant relationships seemed to exist between the owner's financial literacy and each of them, individually; the superficial interpretation of which could be that financial literacy of the SMME owner bears no relationship with the growth of the business; especially if finance experts can be retained as consultants or employees by the business.
\end{abstract}

Keywords: Small, Micro and Medium Enterprises (SMMEs); Financial literacy, Entrepreneurship; Owner-Manager; business growth

\section{Introduction}

The changing global business arena, with its abundance of financial and other information sources, has resulted in a need for information to be processed, understood and analysed by individuals who cannot necessarily make an authentic connection between the financial numbers and the real business world context (Gouws \& Shuttleworth, 2009:142). This could be why concern about financial literacy has increased in recent years, and many countries have embarked on programmes and other research initiatives to introduce and enhance financial literacy among their populations. According to Braunstein and Welch (2002: 445), financial literacy, or the lack thereof, has gained the attention of a wide range of banking corporations, government agencies, educational institutions, consumer and community interest groups, and other businesses.

While Gavigan (2010) views financial literacy as the ability to make informed judgments and effective decisions regarding the use and management of money, Remund (2010:279) defines financial literacy as the degree to which one understands key financial concepts and possesses the ability and confidence to manage personal finances through appropriate, short-term decision-making and sound, long-range financial planning. The view of the construct of financial literacy adopted by this study relies upon the definitions proposed by Remund (2010) and Gavigan (2010). In this study, financial literacy is regarded as the ability of an SMME owner to make appropriate financial decisions and plan for future financial needs.

The other important construct of business growth examined in the study is based upon Wickham's (1998) model of the dynamics of business growth. Wickham (1998:223) argues that due to the multifaceted nature of business, it is important to constantly view the growth and development of a business from four major perspectives: the financial, the strategic, the structural and the organisational. It is along these dimensions that businesses, including SMMEs grow.

In South Africa, the development of SMMEs, according to Nieman and Nieuwenhuizen (2009:275) has been identified as a priority concern, largely because of the sector's ability to create jobs. 73 percent of South Africa's workers are employed by businesses with less than 50 employees; and 45 percent of all employed people work in firms with less 
than 10 employees (SBP Business Environment Specialists, 2009:3). These figures underline the central role that small businesses play in the South African economy. Owner financial literacy, which could enhance the propensity of growth of small businesses, therefore appears worthy of scholarly attention, if the much needed SMME growth is to be realised.

\section{Problem Statement}

Brinckmann, Salomo and Gemuenden (2011:218) claim that financial resources are key resources for the acquisition and configuration of other resources. Financial resources enable a new firm to acquire other resources and serve as an important intermediary in the resource configuration process (Alsos, Isaksen, \& Ljunggren, 2006). Given the pivotal role of finances in the scheme of a business, it is plausible to argue that to perform well, business entities would require financially literate individuals who can manage this important resource while actively participating in business decisionmaking.

One of the identified success factors of a business is the effective use of financial resources and in order for a venture to effectively pursue emerging opportunities, it must be able to access the right resources; one of which is finances (Wickham, 2006:196). Unfortunately, Lindeloef and Loefsten (2005) note that small business owners frequently lack oversight and have limited competence in managing the financial aspects of their business. Cooley and Pullen (1979) also claim that management of firm cash flows is generally not efficient in small businesses. Interestingly, Berman and Knight (2006:28) even found that many people in management positions didn't know the difference between an income statement and a balance sheet. The dearth of business owners who are financially illiterate can bode dire consequences for the continued existence and possible growth of the business. It is against this background that financial literacy is growing in importance, (Tatom, 2006:2) in businesses.

In the specific South African case, a study conducted by the Small Business Advisory Bureau with over 500 respondents drawn from businesses associated with organisations such as SAB Limited, Business Partners, Khula and Seda, found that two-thirds scored less than $60 \%$ on a basic financial literacy test (Branam, 2008). Lack of financial knowledge could possibly be a constraint to proper financial management and consequently, business growth. The proof of the stunted growth of small business is provided by surveys of over 28,000 SMMEs in Africa and Latin America which showed that less than 3\% of them showed growth after start-up (Liedholm, 2002; Mead \& Liedholm, 1998). These findings make the investigation of the issue of financial literacy among business owners necessary.

The study therefore sets out to find answers to the questions:

1. Do SMME owners consider themselves as financially literate?

2. Do SMMEs show signs of financial, strategic or structural growth?

3. Is there a relationship between owner's perceived financial literacy and business growth?

\section{Literature Review}

\subsection{Financial Literacy}

Al-Tamimi and Kalli (2009:500) posit that financial literacy has gained the interest of various groups including governments, bankers, employers, community interest groups, financial markets and other organisations. The importance of improving financial literacy seems to have increased because of factors such as the development of new financial products and the complexity of financial markets, among others.

A study by the OECD (2005) involving businesses in twelve countries including the USA, UK, Australia and Japan, concluded that financial literacy is very low for most respondents. Kotzè and Smith (2008:156-157) revealed that the ratio of household debt to disposable income in South Africa fluctuated between $50.6 \%$ and $71.8 \%$ between 1996 and 2006 . Associated with this, is the savings rate that has declined sharply from $8 \%$ in the 1980 s to about $-0.5 \%$ of personal disposable income in 2006 (Kane-Berman \& Tempest, 2007:87). Mounting personal debt triggered insufficient savings among South Africans (Grawitzky, 2003:57). All of these could be due to financial illiteracy on the part of many South Africans. This situation is problematic as it could affect the individual and economic growth in the country (Kotzè \& Smith, 2008:156-157). If this is the case, then it is pertinent to question whether financial literacy has any relationship with the growth of SMMEs, owned by members of the larger South African population.

Huston (2010:296) states that despite its importance, academic literature has given little attention to financial literacy and how it is measured. The terms financial literacy, financial knowledge and financial education appear to be used interchangeably in literature and this does not help the emergence of a common understanding of the construct. 
However, Gouws and Shuttleworth (2009:146) state that the term 'financial' refers to the information dimension; the term 'literacy' refers to the mental processes of individuals when using this information. This implies that in an organisational context, both the information system (matter) and the human behaviour system (mind), can only become more than their individual parts if they are linked by an interface that can enhance the feed forward (prediction) and feedback action between them (Gouws \& Shuttleworth, 2009:146). McDaniel, Martin and Maines (2002:139) describe financial literacy as the ability to read and understand basic financial statements. Nadler (2009:48) defines business financial literacy as the ability to:

- Read and understand a balance sheet, income statement and cash flow statement.

- Seek feedback when financial statements are inaccurate or confusing.

- Use the information to improve decision-making.

- Understand the limits of financial information.

\subsection{Business Growth}

Wickham (1998:223) views business growth from four interdependent perspectives: financial, strategic, structural and organisational. These are contained in Wickham's model of the dynamics of business growth (see figure 1). A business owner has to consider all of them when planning for growth. The neglect of one element could cause business failure or lead to other problems (Nieman \& Nieuwenhuizen, 2009:276).

Figure 1: Dynamics of business growth

Source: Adapted from Wickham (1998)

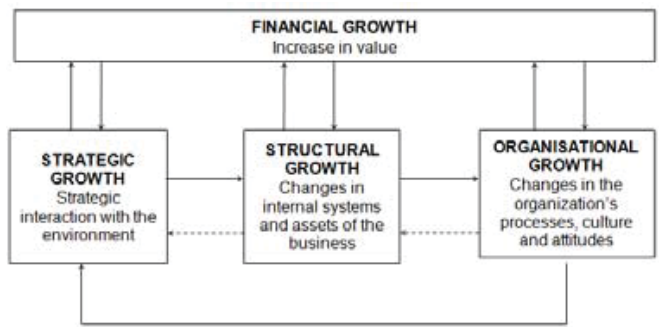

\subsubsection{Financial growth}

Wickham (2006:516) defines financial growth as the development of the business as a commercial entity. It is concerned with increases in turnover, the costs and investment needed to achieve that turnover, and the resulting profits. It is also concerned with increases in the assets of the business. This study utilises measures of financial growth as proposed by Wickham (2006), particularly:

- Changes in total assets;

- Changes in capital;

- Changes in turnover; and

- Changes in profit.

\subsubsection{Strategic growth}

Strategic growth relates to changes that take place in the way in which the organisation interacts with its environment as a coherent strategic whole. Primarily, this is concerned with the way the business develops its capabilities to exploit the market. According to Wickham (2006:516) it is associated with the profile of opportunities which the business exploits and the assets, both tangible and intangible, it acquires to create sustainable competitive advantages. The measures used in this study for strategic growth are taken from those proposed by Wickham (2006), specifically:

- Changes in sales and/or production volumes;

- Changes in cost of sales/production;

- Changes in customer base. 


\subsubsection{Structural growth}

Structural growth relates to the changes in the way the business organises its internal systems, in particular, managerial roles and responsibilities, reporting relationships, communication links and resources control systems (Wickham, 2006:516). This study utilises measures of structural growth as proposed by Wickham (2006), viz:

- Changes in number of employees; and

- Changes in the size and/or location of business premises.

\subsubsection{Organisational growth}

Organisational growth relates to the changes in the business's processes, culture and attitudes as it grows and develops. It is also concerned with the changes that must take place in the owner's role and leadership style as the business moves from being a 'small' to 'large' firm (Wickham, 2006:516). For the purpose of this study the organisational growth dimension is excluded. This is because of the wide discrepancy in the interpretation and understanding of Wickham's (2006) proposed measures for organisational growth, by respondents in the pilot of this study.

\section{Hypothesis}

Gouws and Shuttleworth (2009:141) state that an individuals' decisions and subsequent actions flow from their understanding of the surroundings in which they operate. In order to facilitate economic and financial sustainability, individuals need the cognitive ability to understand financial information.

This appears to be an argument for the value of financial literacy as it pertains to business growth and provides the premise for the study to hypothesise that:

$\mathrm{H1}$ : There is no relationship between the SMME owners' financial literacy and business growth.

$\mathrm{H} 1_{\mathrm{A}}$ : There is a relationship between the SMME owners' financial literacy and business growth.

\section{Research Design}

The research is an ex-post-facto and cross-sectional empirical study. Establishing the universe for the small business sector for statistically valid sampling purposes presents a unique challenge in conducting small business studies (FinMark Trust, 2010:4). Therefore, for the purpose of this study, non-probability sampling methods were used. A combination of judgement and snowball sampling was used in the study. The local chamber of commerce was approached and they suggested SMME owners that met the requirements of the study, who in turn also recommended other SMME owners.

Questionnaires were used as the research instrument and the collected data was statistically analysed. The structured questionnaire consisted of 27 questions that were mostly of the close-ended type. After pilot testing, the questionnaire was distributed to 105 respondents. Most of the respondents included in this research resided and operated their businesses in Gauteng. This is to be expected as FinScope South Africa Small Business Survey indicated that, during 2010, most small business owners (23\%) resided in Gauteng (FinMark Trust, 2010:7). Study respondents needed to meet the following requirements:

- Their business had to have been trading for at least three years;

- Their business had to have no more than 50 employees and

- The turnover of their business had to be under R50 million per annum.

75 of the distributed questionnaires were returned. This indicates a response rate of $71 \%$. Of the pool of returned questionnaires however, only 70 were complete and used for the study.

\section{Presentation of Findings}

\subsection{Financial literacy}

SMME owners in the sample were asked whether they kept financial records. A total of 68 respondents indicated that they did. 52 respondents indicated that the records were up-to-date and 16 respondents indicated that their records were not. Table 1 shows the kinds of financial records that the various SMME owners kept. 
Table 1: Financial records kept by SMME owners

\begin{tabular}{|l|c|}
\hline \multicolumn{1}{|c|}{ Financial record } & Number of respondents \\
\hline Source documents & 66 \\
\hline Journals & 42 \\
\hline Ledgers & 40 \\
\hline Financial statements & 60 \\
\hline Payroll & 38 \\
\hline
\end{tabular}

The table shows that not all SMME owners kept the same kind of records. They seemed to have different combinations of financial documentation that they claimed to have kept. An overwhelming majority of respondents (94\%) kept source documents that included purchase slips, invoices, credit notes, bank statements etc. This percentage is higher than that of the FinScope survey (FinMark Trust, 2010:26) which found that 46\% of small business owners kept financial records.

The study also sought to determine whether the SMME owners perceived themselves as financial literate or otherwise and whether they had received any form of financial training and/or education, in the past.

As shown in table $2,50 \%$ of the respondents considered themselves to be fairly financially literate. Only 4 respondents (5.71\%) considered themselves, illiterate when it comes to financial issues.

Table 2: SMME Owners' perceived financial literacy levels

\begin{tabular}{|l|c|c|}
\hline Perception of levels of financial literacy & Frequency (n) & Percent (\%) \\
\hline Illiterate & 4 & 5.71 \\
\hline Fairly literate & 35 & 50 \\
\hline Very literate & 31 & 44.29 \\
\hline Total & 70 & 100.00 \\
\hline
\end{tabular}

$57 \%$ of respondents indicated that they had received some type of financial training or education in the past while $43 \%$ of the respondent population had not received any such training.

Figure 2: Financial training/education

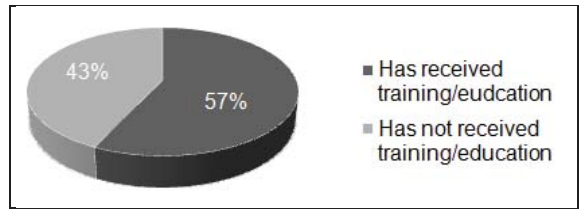

The study attempted to match the SMME owner's perception of their levels of financial literacy with their responses related to whether they had received some form of financial training or education in the past.

Table 3: Cross tabulation of owners' perceived financial literacy levels and financial training and/or education received

\begin{tabular}{|l|c|c|c|}
\hline $\begin{array}{c}\text { Perceived financial } \\
\text { literacy level }\end{array}$ & $\begin{array}{c}\text { Owner has received } \\
\text { financial training/education } \\
(\mathbf{n})\end{array}$ & $\begin{array}{c}\text { 'Owner has not received } \\
\text { financial training/education } \\
(\mathbf{n})\end{array}$ & Total \\
\hline Illiterate & 4 & 0 & 4 \\
\hline Fairly literate & 15 & 20 & 35 \\
\hline Very literate & 21 & 10 & 31 \\
\hline Total & 40 & 30 & 70 \\
\hline
\end{tabular}

Based on the statistical analysis of the owners' perception of their financial literacy and whether they have received any financial training or education, results show that owners who had received training and/or education answered the question related to the perception of their financial literacy differently from owners who had not received any financial training and/or education.

Interestingly, the 4 respondents who considered themselves financially illiterate had received some form of 
financial training and/or education in the past. Clearly, their view suggests that the financial training/education they had been exposed to, could not change their state. There were 20 respondents who had received no financial training and/or education and yet considered themselves fairly financially literate. This is quite curious but perhaps they had acquired their financial knowledge on-the-job, through the practice of managing the finances of their different businesses.

Further statistical testing of the association of owners' perceptions of their financial literacy and their exposure to some form of financial training/education was undertaken. A chi-square test and a Fisher's exact test showed statistically significant results for the relationship between these variables. The chi-square result was 0.0072 while the result of Fisher's exact test 0.0045 . These results suggest the existence of a relationship between the SMME owners' perception of their financial literacy and their exposure to financial training/education.

\subsection{Business growth}

Three elements in Wickham's dynamics of business growth model (1998) were used in the measurement tool to determine whether the SMME owners' businesses showed business growth. These are the elements of Financial, Structural, and Strategic growth. SMME owners responded to questions seeking to determine whether certain aspects (measurements of growth) in their business increased, stayed the same or decreased.

Table 4: Aspects of financial growth

\begin{tabular}{|l|c|c|c|}
\hline Aspects of financial growth & Increased (n) & Stayed the same (n) & Decreased (n) \\
\hline Asset value & 48 & 18 & 4 \\
\hline Capital & 47 & 21 & 2 \\
\hline Turnover & 54 & 13 & 3 \\
\hline Profit & 52 & 14 & 4 \\
\hline
\end{tabular}

The table shows that the majority of businesses' claimed increases related to all the financial growth variables of asset value, capital, turnover and profit, considered in the study. It is worrisome though that $30 \%$ of the respondents conceded that the capital deployed in their business had witnessed no increase. Collaterally, $25.7 \%$ of the SMMEs studied reported that their assets remained unchanged. This indicates some form of stagnation. If it is assumed that such businesses are making profit, then it can be argued that no portion of such profits are been ploughed back into the business. This does not bode well for the growth of the business.

Aspects of the strategic growth of a business and how the businesses in the respondent population of this study fared are shown in table 5 . The strategic growth variables showed that the majority of businesses in the sample claimed to experience increases in all aspects measured.

Table 5: Aspects of strategic growth

\begin{tabular}{|l|c|c|c|}
\hline Aspects of strategic growth & Increased $(\mathbf{n})$ & Stayed the same (n) & Decreased (n) \\
\hline Sales and/or production volumes & 56 & 11 & 3 \\
\hline Cost of sales and/or production & 51 & 15 & 4 \\
\hline Customer/client base & 54 & 10 & 6 \\
\hline
\end{tabular}

While $80 \%$ of the respondents witnessed an increase in sales and/or production volumes, $73 \%$ experienced sales and/or production costs increases while $77 \%$ indicated that their customer/client base had increased.

To measure the structural growth, two variables were utilised. These are the change in the number of fulltime employees and changes to business premises. $57 \%$ of the SMME owners indicated that the number of employees in their businesses stayed the same. $32.9 \%$ revealed that they had increased their number of full time employees while $10 \%$ had experienced a decrease in their fulltime employee numbers (see table 6 ).

Table 6: Aspects of structural growth

\begin{tabular}{|l|c|c|c|}
\hline Aspects of structural growth & Increased ( $\mathbf{n})$ & Stayed the same (n) & Decreased (n) \\
\hline Number of fulltime employees & 23 & 40 & 7 \\
\hline Change in business premises & 23 & 46 & 1 \\
\hline \multicolumn{4}{|c}{402}
\end{tabular}


In terms of changes to the business premises, $65.7 \%$ had witnessed no size changes in their business premises. $32.9 \%$ had experienced an increase in the size of their business premises while only $1.4 \%$ of the respondents have had to move to smaller business premises. .

To be able to analyse the growth results further and compare the owners responses to other variables, each business was awarded a growth score. 1 point was awarded for "decrease", 2 points for "stayed the same", and 3 points for "increase" responses. This cuts across the three growth dimensions and nine component aspects of growth utilised in the study. Respondents could therefore earn a minimum score of 9 and a maximum score 27 . For the study, the lowest score a business received was 12 and the highest score earned was 27 . Table 7 provides a summary of the growth scores.

Table 7: Business growth scores

\begin{tabular}{|c|c|c|}
\hline $\begin{array}{c}\text { Aggregate growth } \\
\text { scores of SMMEs }\end{array}$ & Frequency (n) & Percent (\%) \\
\hline 12 & 1 & 1.43 \\
\hline 13 & 1 & 1.43 \\
\hline 16 & 1 & 1.43 \\
\hline 18 & 4 & 5.71 \\
\hline 19 & 2 & 2.86 \\
\hline 20 & 4 & 5.71 \\
\hline 21 & 1 & 1.43 \\
\hline 22 & 2 & 2.86 \\
\hline 23 & 7 & 10.00 \\
\hline 24 & 19 & 27.14 \\
\hline 25 & 11 & 15.71 \\
\hline 26 & 13 & 18.57 \\
\hline 27 & 4 & 5.71 \\
\hline Total & 70 & 100.00 \\
\hline
\end{tabular}

The median score was used as a basis for categorising the SMMEs into two groups. The first group included all SMMEs that obtained scores lower or equal to the median score of 24. This group was categorised as SMMEs with "low to average growth' and included all the businesses with growth scores in the range of 12 to 24 . The second group of SMMEs were categorised as 'high growth' businesses and included businesses with growth scores above the median score. This second cohort of businesses had obtained growth scores in the 25 to 27 points range. Based on this categorisation, the 'high growth' and 'low to average growth' categories comprised 28 and 42 SMMEs respectively. To summarise, the data showed information contained in table 8 , with regard to the business growth of SMMEs.

Table 8: Summary of different forms of growth

\begin{tabular}{|c|c|c|}
\hline Financial Growth & Strategic Growth & Structural Growth \\
\hline $\begin{array}{l}\text { - } 48 \text { respondents' asset value } \\
\text { increased; } \\
\text { - } 47 \text { respondents' capital increased; } \\
\text { - } 54 \text { SMMEs' turnover increased; } \\
\text { - } 52 \text { SMMEs' profit increased. }\end{array}$ & $\begin{array}{l}\text { - } 56 \text { businesses' sales and/or production volumes } \\
\text { increased; } \\
\text { - } 51 \text { businesses' cost of sales and/or production } \\
\text { increased; } \\
\text { - } 54 \text { SMMEs' customer and/or client base } \\
\text { increased. }\end{array}$ & $\begin{array}{l}23 \text { businesses' number of fulltime } \\
\text { employees increased. } \\
\text { - } 23 \text { businesses' premises increased } \\
\text { in size. }\end{array}$ \\
\hline
\end{tabular}

\subsection{Hypothesis testing}

The hypothesis suggested an association (or lack of it) between the SMME owners' financial literacy and business growth. The $p$-value for the test of the hypothesised relationship between the owner's perceived financial literacy and business growth was 0.0582 . This implies the non-existence of a statistically significant relationship between the two variables at a 0.05 level of significance. This provides the basis for accepting the study's null hypothesis which states that:

There is no relationship between the SMME owners' financial literacy and business growth. 
This curious result encouraged the study to investigate possible associations between perceived financial literacy and the nine different aspects of growth utilised in the study. Each growth variable was therefore tested for a possible relationship with the owners' perception of their financial literacy.

The $p$-value for the expected association between owner's perceived financial literacy and increase in asset value was 0.1793 , which reflects that the relationship is not statistically significant. Similar results were obtained for the test of association between owner's perceived financial literacy and the other business growth aspects used in the study.

Table 9: Perceived financial literacy and aspects of business growth

\begin{tabular}{|c|c|c|}
\hline & Relationships between variables & p-value \\
\hline \multirow{4}{*}{$\begin{array}{l}\text { Financial } \\
\text { Growth }\end{array}$} & Perceived financial literacy and asset value & 0.1793 \\
\hline & Perceived financial literacy and capital & 0.8090 \\
\hline & Perceived financial literacy and turnover & 0.7435 \\
\hline & Perceived financial literacy and profit & 0.8696 \\
\hline \multirow{3}{*}{$\begin{array}{l}\text { Strategic } \\
\text { Growth }\end{array}$} & Perceived financial literacy and sales and/or production volumes & 0.6181 \\
\hline & Perceived financial literacy and cost of sales and/or production & 0.8464 \\
\hline & Perceived financial literacy and customer and/or client base & 0.8563 \\
\hline \multirow{2}{*}{$\begin{array}{c}\text { Structural } \\
\text { Growth }\end{array}$} & Perceived financial literacy and number of fulltime employees & 0.6534 \\
\hline & Perceived financial literacy and changes to premises & 0.3589 \\
\hline
\end{tabular}

For instance, the comparison between the owners' perceived financial literacy and the change in capital in the business showed that respondents answered the question similarly regardless of their perceived level of financial literacy given the fact that the p-value obtained was 0.8090 .

Going by the realised p-values (as shown in table 9), there is also no indication of a statistically significant relationship between the owners' perceived financial literacy and the business turnover, profit, sales and/or production volumes, cost of sales and/or production, changes in the customer and/or client base, changes in the number of fulltime employees or changes to the business premises.

\section{Discussion of Findings}

The purpose of the research was to determine whether SMME owners in South Africa considered themselves as financially literate, whether the SMMEs showed signs of growth and if a relationship existed between the SMME owner's perception of their financial literacy and business growth. To realise the purpose of the research three questions were posed and the findings revealed by the study concerning these questions are discussed in this section.

\subsection{Do SMME owners consider themselves as financially literate?}

$57 \%$ of respondents in the study indicated that they had received some form of financial literacy training and/or education. 4 owners considered themselves illiterate, 35 owners considered themselves fairly literate, 31 owners considered themselves very literate.

Based on these findings, majority of the SMME owners in the sample consider themselves as financially literate. This may be due to the fact that a lot of them had received some form of financial training and/or education, perhaps due to their membership of the chamber of commerce. While membership may not be an indicator of financial literacy, it could be a reflection of the education, exposure or enlightenment of the SMME owners. This could mean that the SMME owner who is a member of a chamber of commerce is more aware of the issues, like financial literacy, that are critical to the business and has therefore made an effort to develop this competency. This may not exactly be the case in the larger South African SMME population.

From a technical perspective, it is important to note that the sample used in this study was not randomly drawn and so the results cannot be generalised to all SMME owners in South Africa.

\subsection{Do SMMEs show signs of financial, strategic or structural growth?}

The study revealed that a greater portion of the respondents suggested that their businesses were growing, particularly along the financial and strategic dimensions. An average $71.4 \%$ of the respondents claimed an increase along the 
financial dimension of growth. An average $77.1 \%$ suggested that their businesses had witnessed strategic growth.

Curiously, these percentages were not so high when it comes to the more tangible and visible dimension of structural growth. Only an average $32.9 \%$ of the respondents claimed there was a structural growth in their businesses while there was no structural growth for $61.4 \%$ of the businesses in the sample. The implication of this could be either that the owners are not re-investing sufficiently in their businesses or that they lack the entrepreneurial inclination for growth. Whatever the case may be, the finding does not exactly augur well for small business growth.

\subsection{Is there a relationship between owner's perceived financial literacy and business growth?}

Statistical analysis suggest that the answer to this question is no. According to the data from this sample and consequent hypothesis tests, there is no relationship between owners' perceived financial literacy and business growth. The null hypothesis expressing the absence of a relationship between the variables was accepted at a 0.05 level of significance given that the p-value was 0.0582 .

Statistical tests that were undertaken to determine if a relationship existed between owner's financial literacy and different aspects of business growth as outlined by Wickham (1998). All of the results obtained showed that there was no statistically significant relationship between the independent variable of owner's financial literacy and the different dependent variables of aspects of business growth along the financial, strategic and structural dimensions.

\section{Conclusion}

The research showed that there is a relationship between the owners' perceived financial literacy and their level of financial education and/or training. This implies that exposure to training and education improves an individual's rating of his/her competency in any specific area. The study also showed that the small businesses in the sample showed signs of growth; particularly along financial and strategic dimensions even if the extent of the suggested growth was not measured.

The study failed to statistically link the business owner's financial literacy to business growth. It therefore, on face value, seems to contradict the logic that it would be implausible for a financially illiterate business owner to grow a business. Furthermore, the findings of the study could be seen as countering those of Kotzè and Smit (2008) who found that personal financial education is essential to obtaining knowledge that could assist individuals in managing financial affairs effectively.

In essence though, the conclusion that the study seems to contradict the position of Kotzè and Smit (2008) is not necessarily the case. This is because the study did not make any differentiation between SMMEs whose owners, even if not financially literate, had employed financially literate persons to assist in managing the affairs of the organisation. Indeed the results of the study, as it pertains to the issue of financial management, given its importance in a business context, seems to be that SMMEs whose owners are not financially literate could possibly be leveraging on the competence of others in this very important area.

The lesson therefore is that an SMME owner is not necessarily at a disadvantageous position even though he/she is financially illiterate in so far as another individual who is financially literate aids the business' decision-making in the specific area of finance because as Kotze and Smit (2008) argue, individuals with a knowledge of financial management can reduce the effects and consequences of the mismanagement of finances.

\section{Further Research}

Future research could therefore explore the hypothesised relationship between financial literacy and business growth by looking beyond the SMME owners to determine if a business that makes use of financially literate people (whether they are employees or consultants) shows improved growth as compared to those that do not have or use individuals with such a competency. A future study of a similar nature may generate deeper insights if it takes a longitudinal rather than a cross-sectional approach to data collection.

\section{References}

Alsos, G., Isaksen, E. \& Ljunggren, E. (2006). New venture financing and subsequent business growth in men- and women-led businesses. Entrepreneurship Theory and Practice, 30(5):667-686.

Al-Tamimi, H. \& Kalli, A. (2009). Financial literacy and investment decisions of uae investors. The Journal of Risk Finance, 10(5):500- 
516 .

Anthes, W. (2004). Financial illiteracy in America: A perfect storm, a perfect opportunity. Journal of Financial Service Professionals, 58(6):49-56.

Bateman, H., Eckert, C., Geweke, J., Louviere, J., Thorpe, S. \& Satchell, S. (2012). Financial competence and expectations formation: evidence from Australia. Economic Record, 88(280):39-63.

Berman, K. \& Knight, J. (2006). Financial intelligence: manager's guide to knowing what the numbers really mean. Boston, MA: Harvard Business School Press.

Branam, C. (2008). The South African Small Business Environment. Paper presented at the Southern African Catholic Bishops Conference, Cape Town, July 2008:1-9.

Braunstein, S. \& Welch, C. (2002). Financial literacy: an overview of practice, research, and policy. Federal Reserve Bulletin, November: $445-457$.

Brinckmann, J., Salomo, S. \& Gemuenden, H. (2011). Financial management competence of founding teams and the growth of new technology-based firms. Entrepreneurship Theory and Practice, 35(2):217-243.

Cooley, P. \& Pullen, R. (1979). Small business cash management practices. American Journal of Small Business, 2(October):1-11.

Cude, B.J. (2010). Financial Literacy 501. The Journal of Consumer Affairs, 44(2) 271-275.

FinMark Trust. (2010). FinScope South Africa small business survey 2010. [Online] Available: http://www.finscope.co.za/new Iscriptlibrary/getfile.aspx?filename=FS\%20Small\%20Business_\%20reportFNL.pdf\&file=../module_data/abb94be2-c25b-4e2b8fea-b4cb8cf019ab/downloads/21d7d26f-46a3-4f3b-be30-ed946504a3bf.file. (July 10, 2012).

Gavigan, K. (2010). Show me the money resources: Financial literacy for 21st century learners. Library Media Connection 28(5):24-27.

Gouws, D. \& Shuttleworth, C. (2009). Financial literacy: an interface between financial information and decision-makers in organisations. South African Business Review 13(2):141-165.

Grawitzky, R. (2003). Pay now, worry later, South African Labour Bulletin. 27(2): 52.

Huston, S. (2010). Measuring financial literacy. Journal of Consumer Affairs, 44(2):296-316.

Kane-Berman, J. \& Tempest, J. (eds). (2007). South Africa survey 2006/2007. Johannesburg: South African Institute of Race Relations.

Kotzè, L. \& Smith, A. (2008). Personal finances: What is the possible impact on entrepreneurial activity in South Africa? Southern African Business Review, 12(3):156-172.

Liedholm, C. (2002). Small firm dynamics: Evidence from Africa and Latin America. Small Business Economics, 18(3): 225-240.

Lindeloef, P. \& Loefsten, H. (2005). Academic versus corporate new technology-based firms in Swedish science parks: An analysis of performance, business networks and financing. International Journal of Technology Management, 31(3/4), 334-357.

McDaniel, L., Martin, R. \& Maines, L. (2002). Evaluating financial reporting quality: The effects of financial expertise vs. financial literacy. The Accounting Review, 77(2002):139-167.

Mead, D. \& Liedholm, C. (1998). The dynamics of micro and small enterprises in developing countries. World Development, 26(1): 6174.

Nadler, M. (2009). Financial Literacy means more than investment education. [Online] Available from: http://www.benefitnews.com. (July $6,2011)$.

Nieman, G. \& Nieuwenhuizen, C (eds). (2009). Entrepreneurship: A South African Perspective. $2^{\text {nd }}$ edition. Hatfield: Van Schaik Publishers.

OECD (Organisation for Economic Cooperation and Development). (2005). Improving Financial literacy: Analysis of issues and policies. France: OECD Publishing.

Remund, D. (2010). Financial literacy explicated: The Case for a clearer definition in an increasingly complex economy. Journal of Consumer Affairs, 44 (2): 276-295.

SBP Business Environment Specialists. (2009). Small Business Development in South Africa. [Online] Available from: www.sbp.org.za. (May 1, 2010).

Swart, N. (2005). Why financial literacy is a complete failure. Management Today, May: 48.

Tatom, J. (2006). Lessons on Adult Financial Literacy. [Online] Available: http://www.cashbuffalo.org/sitepages/downloads /research/NFI Financial Literacy.pdf (February 10, 2013)

Wickham, P. (1998). Strategic entrepreneurship: A decision-making approach to new venture creation and management. London: Pitman.

Wickham, P. (2006). Strategic Entrepreneurship.4th edition. Harlow: Pearson Education Ltd. 